\title{
Funding cut for US nuclear waste dump
}

\section{Yucca Mountain's end would leave the country with few alternatives for a long-term repository.}

Some ten billion dollars and two decades into the project, the proposed US nuclear waste dump at Nevada's Yucca Mountain has hit a major and possibly decisive stumbling block: President Barack Obama has proposed eliminating all funding for scientific research on the deep-rock repository, 140 kilometres northwest of Las Vegas. As Yucca Mountain has been the United States' only potential longterm repository since 1987 , the decision once again raises the issue of what to do with the country's high-level nuclear waste.

In his budget for fiscal year 2009, to be released in early May, Obama is expected to propose spending only the estimated US $\$ 40$ million needed to let the Nuclear Regulatory Commission (NRC) move forwards in evaluating the licence application for Yucca Mountain. The licence request, filed last June under George W. Bush's administration, requires the NRC to investigate the site's technical suitability, a process expected to take three to four years.

But the new administration says it will halt the controversial project regardless of the licence ruling, saying that the country can find another solution for long-term management of its nuclear waste. "I think we can do better," energy secretary Steven Chu told the Senate committee on energy and natural resources in March. The Department of Energy has established a commission to explore alternatives, which could report back within a year.

For now, high-level waste remains in cooling ponds and dry-cask storage containers at the country's 104 nuclear power plants. But that is a short-term and expensive solution: since the government missed a 1998 deadline for opening the Yucca Mountain facility, it has been paying fees to the power plants, a bill that could rise to $\$ 11$ billion by 2017 . Some states have threatened to stop contributing unless an alternative to Yucca Mountain is found.

Tom Kauffman, a spokesman for the industry policy group the Nuclear Energy Institute, says that waste can be safely stored on-site "indefinitely" while a long-term solution is found, but others say an answer is needed. "I live in a state with three [nuclear] power plants," says Michael Corradini, a nuclear engineer at the University of Wisconsin in Madison. "It's very unsatisfying to not have a complete, thought-out process."

One possibility is to begin searching for another geologic repository. Yucca Mountain's capacity was to be legally capped at 70,000

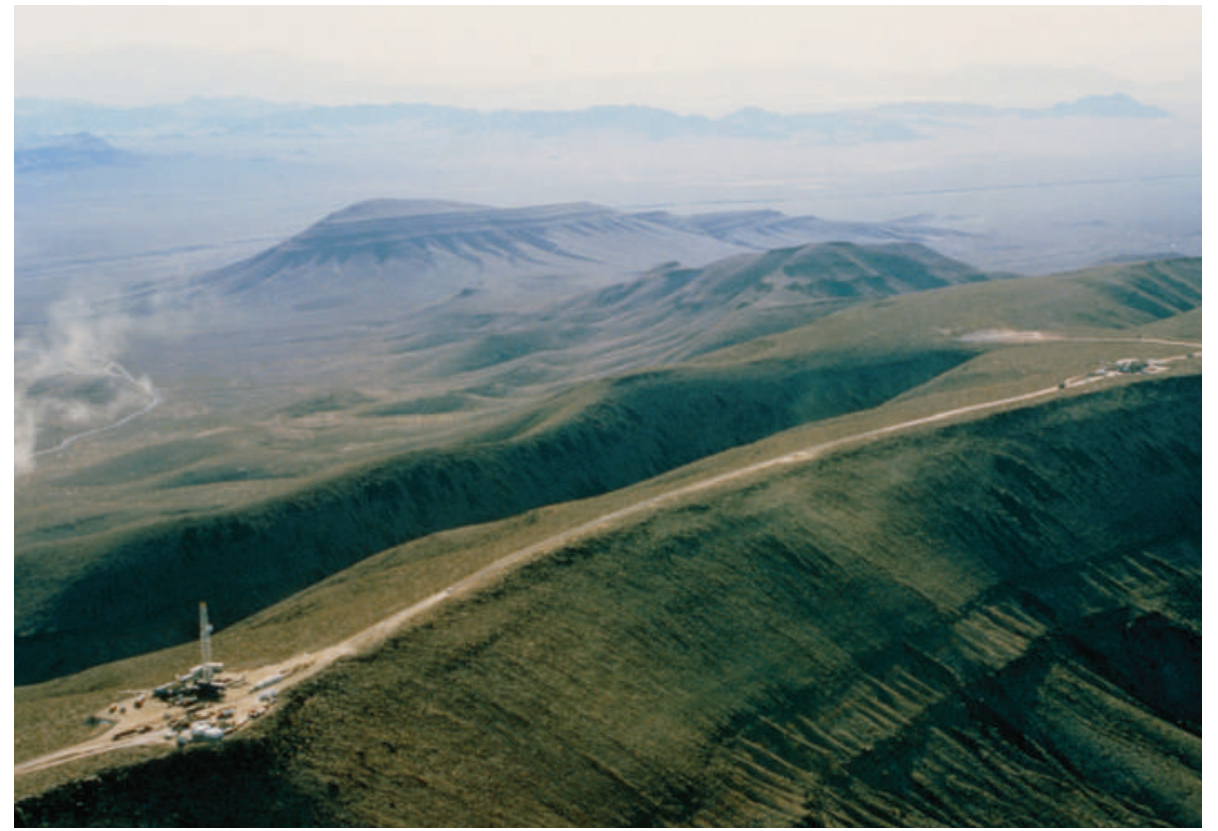

Billions of dollars spent on the proposed Yucca Mountain repository could be wasted.

tonnes of nuclear waste, even though it could technically hold 4-9 times that amount, so the US government had intended to open a second site, says Charles McCombie, a nuclear-waste consultant based in Gipf-Oberfrick, Switzerland. "It would be sensible for the United States to begin looking at another repository-siting

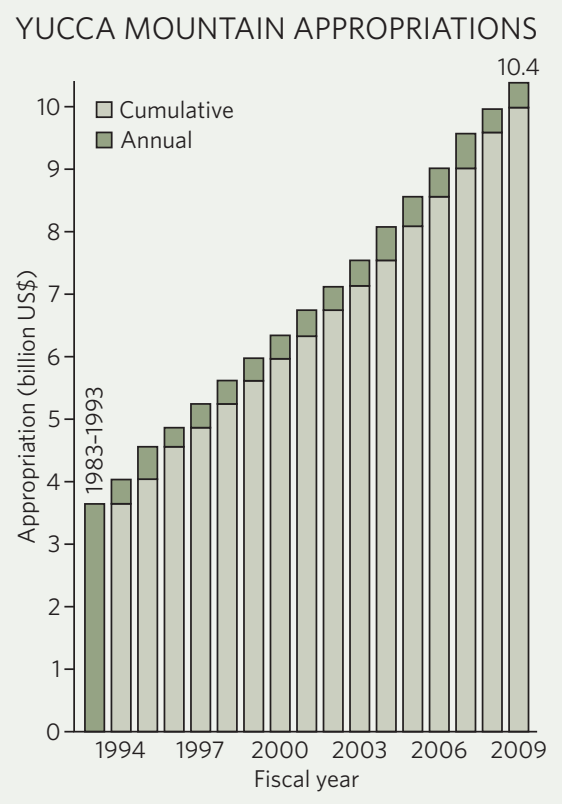

programme, whether or not Yucca Mountain shapes up," he says.

But the government has spent decades studying Yucca Mountain as the only potential site, spending more than $\$ 10$ billion (see chart) to evaluate its geologic suitability. And few are enthusiastic about restarting the bitter political arguments over where to put a repository. Sites in Washington state and Texas, which were under consideration until Nevada was controversially selected, might be options, as is an area in southeast New Mexico near the Department of Energy's Waste Isolation Pilot Plant, which stores military nuclear waste and where the local community has expressed interest in hosting a site.

\section{Starting anew}

The political challenges surrounding Yucca Mountain might prompt the Obama administration to take a fresh look at reprocessing: purifying plutonium-239 and uranium-235 and recycling those fuels to reduce the waste's mass and volume. Because the pure materials can be used in nuclear weapons, the US suspended reprocessing of spent fuel in 1977. The previous administration began a programme, the Global Nuclear Energy Partnership, to explore an international reprocessing project, but Congress gave the programme less than half the money 
that Bush requested. Under Obama, the project may stop altogether.

"Leaving it where it is, putting it centrally or reprocessing it can all be done. But in all cases, there has to be a final resting point for the solid waste," says Corradini. "It's pretty clear from an international perspective that geologic disposal of high-level waste, and probably of any nuclear waste, is the favoured option," adds John Garrick, chairman of the US Nuclear Waste Technical Review Board, based in Arlington, Virginia.

Some countries are well on their way towards siting a repository: Finland is working on a repository at Olkiluoto, which could be operational by 2020 . Sweden is finalizing research on two candidate disposal sites and expects to choose one by the end of the year.

In both Finland and Sweden, the key to success was that governments adopted a cautious time schedule and a stepwise approach and involved the local community from the start, says Barbara Pastina, a nuclear-waste scientist at the Helsinki-based engineering firm Saanio and Riekkola Oy. In Finland, she says, "the whole nation was represented in the decision to build the repository" at Olkiluoto. The community had the right to veto the location at the beginning, and parliament voted on the decision. After early setbacks, Canada and the United Kingdom are also on track to find geologic repositories for long-term storage. Canada reorganized its national waste-management efforts in 2002 and is moving towards a siting phase, whereas the United Kingdom restarted in 2001.

By contrast, powerful states' efforts to avoid hosting the repository have stymied US attempts to find a site. Senator Harry Reid (Democrat, Nevada), now the Senate majority leader, has fiercely opposed the project from the beginning, and many Nevadans are still fighting the Yucca Mountain proposal. “They've always felt that it was hoisted on them rather than them volunteering," says Todd Allen, an assistant professor of nuclear engineering at the University of Wisconsin.

Public consent has been the missing ingredient in Yucca Mountain from the beginning, agrees McCombie. The trick to finding another location, he says, is a "modern approach that combines good science with a consensus of enough people that it's the right thing to do". The United States hasn't built a nuclear power plant in three decades, but a resurgence of nuclear power is on the horizon. The NRC is considering licences for 26 new nuclear power plants, and construction could begin as early as $2012-$ increasing the pressure on the country to solve long-term disposal once and for all.

Amanda Leigh Mascarelli

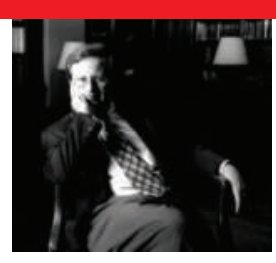

ENERGY-SCIENCE CZAR Steve Koonin heading for US Department of Energy post.

www.nature.com/news

\section{Brain imaging skewed}

\section{Double dipping of data magnifies errors in functional MRI scans.}

Nearly half of the neuroimaging studies published in prestige journals in 2008 contain unintentionally biased data that could distort their scientific conclusions, according to scientists at the National Institute of Mental Health in Bethesda, Maryland.

Experts in the field contacted by Nature have been taken aback by the extent of the methodological errors getting through the supposedly strict peer-review systems of the journals in question.

Nikolaus Kriegeskorte, Chris Baker and their colleagues analysed 134 functional magnetic resonance imaging (fMRI) studies published last year in five top journals Nature, Science, Nature Neuroscience, Neuron and The Journal of Neuroscience. The survey, published in Nature Neuroscience on 26 April (N. Kriegeskorte, W. K. Simmons, P. S. F. Bellgowan and C. I. Baker Nature Neurosci. 12, 535-540; 2009), found that 57 of these papers included at least one so-called 'non-independent selective analysis'; another $\mathbf{2 0}$ may also have done so, but did not provide enough information to confirm suspicions.

The non-independence of the analysis lies in using the same data to set up the conditions to test a hypothesis, then to confirm it. "We are not saying that the papers draw wrong conclusions, because in some cases the error will not have been critical," says Baker. "But in other cases we don't know, and this creates an ambiguity."

"It is a poor reflection on the quality of peer review of prestige journals - they really need to up their game in terms of rigour," says Karl Friston, scientific director of the Wellcome Trust Centre for Neuroimaging at University College London.

Brain imaging provides vast quantities of data in the form of voxels (three-dimensional pixels), from the entire brain. Neuroscientists sometimes focus on an area of interest by searching for voxels that are activated when subjects perform different tasks in an experiment - for example, looking at a face or an inanimate object.

But fMRI data are intrinsically very noisy, producing many 'false voxels'. Problems arise when researchers use the same data to select a particular brain region and then to quantify the experimental effects there - for example, by asking how much more strongly the region responds to a face compared with an inanimate object.

"It is crucial to analyse your results with a set of data that are independent of that used in the earlier selection process," says Chris Baker. "It is even OK to split your total data and use one half to select the voxels, and the other to further analyse the response in these voxels."

A similar type of error has been addressed by Edward Vul of the Massachussetts Institute of Technology in Cambridge and his colleagues (E. Vul, C. Harris, P. Winkielman and H. Pashler, Perspect. Psychol. Sci. 4, 274-290; 2009). A preprint of their research caused uproar in the field earlier this year by referring to 'voodoo correlations' and naming labs it considered guilty of circular analysis (see Nature 457, 245; 2009).

In contrast, the study by Kriegeskorte and Baker does not single out any researchers. "We didn't name names because the error is just too common," says Baker. "And we saw no reason to be personal - our idea was to highlight a problem so people are less likely to fall into the trap."

"This new paper is less controversial, but potentially more worrying," says Friston. "The issue of selection bias doesn't require special understanding of statistics, just the following of good practice - it is not rocket science."

Baker points out that circularity errors creep into many areas of neuroscience.

"It applies equally to single-unit electrophysiology, electroencephalography, gene microarray studies or even behavioural data," he says. But fMRI data are particularly vulnerable because of the complex analysis demanded by their huge volumes, and because so many untrained outsiders are entering the field. "For those of us with a few years of $f M R I$ experience the issue is entirely passé, but there will always be a substantial minority on a steep learning curve," says Friston. "What surprised me is how frequent the errors are."

Baker notes that the increasing complexity of the data "probably leads people to take their eye off the ball so that the more fundamental aspects don't get taken care of". Alison Abbott 